Birgit Henriksen*

\title{
Fremmedsprogspædagogikken - eksemplificeret ved 4 forskningsområder
}

\begin{abstract}
The paper gives a brief introduction to Foreign Language Pedagogy. In order to show the wide scope in research interests and methodology within this field of research 4 specific areas of study are outlined: 1) cross-cultural pragmatics 2) lexical inferencing strategies 3) text quality in written texts and 4) classroom research within the action research paradigm. For each of the fields of study the research design, the results and possible pedagogical implications are outlined. Finally the implications of the results in relation to the teaching of Greenlandic in secondary education in Greenland are discussed.
\end{abstract}

\section{Introduktion}

I mit indlæg vil jeg forsøge at give et indtryk af bredden i fremmedsprogspædagogikkens (FSP) indhold og metode igennem en kort introduktion til 4 forskellige sprogpædagogiske forskningsområder.

Det vil være min intention at præsentere nogle udvalgte forskningsprojekter, der kan illustere FSPs nære tilknytning til andre beslægtede forskningsområder. At netop disse projekter er valgt skyldes, at de berører såvel sprogindlærerens receptive (læse og lytte) som produktive færdigheder (skrive og tale). Derudover giver de valgte områder mulighed for at præsentere både produkt- og proces -orienterede tilgange i den fremmedsprogspædagogiske forskning. Endelig er korte introduktioner til en række af disse arbejder tilgængelige i to nyere antologier om FSP (Kasper og Wagner 1989; Phillipson, Kellerman, Selinker, Sharwood Smith og Swain 1990).

1 Indlæg ved konference for Grønlandskfaget på de Gymnasiale Uddannelser i Grønland, Kangerlussuaq, 20.-25. oktober, 1993.

* Birgit Henriksen

Department of English

University of Copenhagen

80, Njalsgade

2300 Copenhagen $S(D K)$ 
Det er vigtigt at understrege, at dette indlæg naturligvis kun kan give et meget skitseagtigt indblik i de nævnte forskningsemner. De steder og i det omfang, det kan klargøre fremstillingen, vil det være hensigtsmæssigt kort at berøre den valgte forskningsmetode, derefter ganske kort at nævne de vigtigste resultater, og slutteligt antyde nogle pædagogiske implikationer. Efter denne introduktion til de valgte emner vil jeg afslutningsvis kort diskutere, på hvilke punkter jeg mener, grønlandskfaget på GU kan finde inspiration fra den fremmedsprogpædagogiske forskning.

De 4 forskningsområder:

1. Den tvarsproglige pragmatik - illustreret ved CCSARP projektet (The Cross-Cultural Speech Act Realization Project, Blum-Kulka, House og Kasper 1989; Blum-Kulka 1990, 255-271; Edmonson og House 1990, 273-287) og John Gumperz' arbejde med "gatekeeper encounters" (Gumperz 1982).

Se afsnit 3 nedenfor.

2. Indlaring af ordforråd - illustreret ved et projekt om leksikalske gættestrategier (Haastrup 1989, 20-35; Haastrup 1990, 120-133 og Haastrup, 1991) og ved kognitive teorier om faktorer, der fremmer lagring af ord i langtidshukommelsen (Craik og Lockhart 1972, 6784; Jacoby, Craik og Begg 1979, 585-600;Beheydt 1985, 1-18).

Se afsnit 4 nedenfor.

3. Den skriftlige dimension - illustreret ved Nordskriv projektets analyser af tekstkvalitet. (Albrechtsen, Evensen, Lindeberg og Linnarud 1990, 79-91). Herudover vil spørgsmålet om arbejde med en procesorienteret skrivepædagogik (Kock og Tandrup 1989) blive kort berørt.

Se afsnit 5 nedenfor.

4. Padagogisk udviklingsarbejde - illustreret ved et projekt om udvikling af elevers pragmatiske viden og kommunikationsfærdighed i engelskundervisningen i gymnasiet. I denne forbindelse berøres spørgsmålet om integrering af kommunikative arbejdsformer i sprogundervisningen (Henriksen 1988, 171-193; Henriksen 1989, 166-182 og Henriksen, 1990).

Se afsnit 6 nedenfor. 


\section{Fremmedsprogspædagogikkens nabodiscipliner}

Som vist i skema 1 nedenfor grænser FSP op til en række andre beslægtede nabodiscipliner. FSP har som sit teoretiske fundament udgangspunkt i disse forskningsområder, men den videreudvikler teoridannelserne og behandler dem i et sprogpædagogisk perspektiv.

De elementer i skemaet, som er af særlig betydning i forhold til de 4 forskningsfelter, som behandles mere udførligt, vil blive kommenteret løbende i den relevante sammenhæng.

\section{Skema 1. Fremmedsprogspædagogikkens nabodiscipliner}

\begin{tabular}{|ll|}
\hline \multicolumn{2}{|c|}{ SPROGPOLITISKE FORHOLD } \\
\hline LINGVISTIK & KULTURELLE FORHOLD \\
- grammatik & - antropologi \\
- fonetik & - sociologi \\
- semantik & - samfundsstudier \\
- pragmatik & \\
\multicolumn{2}{|c|}{ FREMMEDSPROGSP EDAGOGIK } \\
PSYKOLOGI & PFEAGOGIK \\
- kognitiv psykologi & - almen didaktik \\
- udviklingspsykologi & - fagdidaktik \\
\hline \multirow{2}{*}{ UNDERVISNINGSTRADITION }
\end{tabular}

Med hensyn til de pædagogiske implikationer af forskningsresultaterne indenfor FSP er det vigtigt at understrege, at FSP befinder sig i et spændingsfelt mellem de sprogpolitiske forhold i et givent samfund og undervisningstraditionen i den helt specifikke indlæringssituation/ undervisningssammenhæng, der arbejdes med. Dette betyder naturligvis, at spørgsmålet om den praktiske anvendelse/overførselsværdi af forskningsresultaterne vil være afhængig af forholdene i den bestemte situation, der arbejdes i.

\section{Den tværsproglige pragmatik}

Pragmatikken (se Kasper og Trosborg 1989, 120-134) er et meget stort og ekspanderende forskningsområde, der dels grænser op til de mere 
traditionelle sprogdiscipliner (grammatik, fonetik og semantik) og dels til de kulturelle studier (antropologi, sociologi og samfundsstudier).

Den pragmatiske forskning tager, i modsætning til den formelle sprogbeskrivelse, sit udgangspunkt i den faktiske sprogbrug. Et af de centrale forskningsfelter indenfor dette område er beskrivelsen af de forskellige typer af sproghandlinger, der kan udtrykkes gennem sproget (anmodning, klage, forbud, opfordring, undskyldning, osv.) og de sproglige midler, som sprogbrugeren har til rådighed til at udtrykke disse sproghandlinger med. Især spørgsmålet om det sproglige udtryks hensigtmæssighed ("appropriateness") eller graden af høflighed ("politeness") i forhold til samtalesituationen og vurderinger af forholdet mellem sprogbrugere har optaget forskerne meget.

Den pragmatiske forskning har gennem en række studier af indsamlet data fra sprogbrugere kunnet dokumentere, i hvor høj grad forskellige sprogsamfund har forskellige normer for sproglig adfærd. Den enkelte sprogbruger er oftest ikke bevidst om de tværkulturelle forskelle i de sproglige normer om f.eks. høflighed. Selv to så nært beslægtede sprog som f.eks. engelsk og dansk eller dansk og tysk har forskellige regler for, hvad der regnes for normale og hensigtsmæssige omgangsformer $\mathrm{i}$ forskellige situationer.

Brud på den forventede sproglige adfærd kan få endog meget uheldige konsekvenser for forholdet mellem sprogbrugere fra forskellige kulturer. For sprogindlæreren kan netop de pragmatiske normer være svære at lære, og anekdoter fra det virkelige liv handler meget ofte om, hvordan misforståelser og konflikt er opstået pga. utilsigtede, men uheldige sproglige formuleringer.

\subsection{CCSARP projektet}

CCSARP-projektet (The Cross-Cultural Speech-Act Realization Project, se Blum-Kulka, House og Kasper 1989; Blum-Kulka 1990, 255 271;Edmondson og House 1990, 273-287) er et stort, internationalt forskningsprojekt der, som projekttitlen antyder, forsøger at beskrive og sammenligne, hvilke sproglige udtryksmidler der anvendes til at udføre to udvalgte sproghandlinger (opfordringer og undskyldninger) på en række forskellige sprog (bla. dansk, australsk-engelsk, tysk, argentiskspansk, hebraisk og canadisk-fransk). De data, som danner grundlag for analyserne, er indsamlet ved hjælp af en række små skriftlige rollespil, de såkaldte "discourse completion tasks" (DCTs). 
I disse DCTs er situationen og en del af dialogen gengivet, og man bedes derefter udfylde den manglende replik. I eksemplet nedenfor (se skema 2) er svaret fra samtalepartneren angivet, mens selve "anmodningen" om at låne forelæsningsnoterne netop er den sproghandling, der skal udfyldes.

\section{Skema 2: Eksempel på en "discourse-completion task"}

\section{At the university}

Ann missed a lecture yesterday and would like to borrow Judith's notes.

Ann:

Judith: Sure, but let me have them back before the lecture next week.

Resultaterne fra CCSARP viste, at der er mange lighedspunkter i de sproglige redskaber, som de undersøgte sprog har til rådighed til at udtrykke bestemte sproghandlinger med. F.eks. er brug af modalverber (kan), datidsformen af verbet (kunne) og forskellige små "nedtonere" (vel, et $\varnothing$ jeblik) i mange sprog konventionelle midler til at gøre en anmodning mere indirekte, mindre belastende og dermed mere høflig (“Du kunne vel ikke lige hælpe mig et øjeblik?").

Det er imidlertid ikke overraskende, at sammenligningen af det indsamlede CCSARP-data fra de forskellige sprog også afslørede klare interkulturelle forskelle $\mathrm{i}$, hvilke udtryksmidler der blev valgt $\mathrm{i}$ en bestemt situation. På nogle af sprogene var der f.eks. en tendens til generelt at udtrykke sig mere direkte end på de andre sprog. Derudover viste det sig, at der var kulturelle forskelle på, hvor nært eller fjernt og hvor statusbetinget forholdet mellem samtalepartnerne blev vurderet. Sådanne forskelle i opfattelser af samtalepartnernes indbyrdes forhold vil ofte give sig udslag i forskelle i valget af sproglig udtryksform. Disse kulturbetingede forskelle i tolkningen af f.eks. de talende indbyrdes forhold og situationens formalitetsgrad kan, som allerede nævnt, give anledning til problemer i den interkulturelle kommunikation. 
Resultater fra pragmatiske undersøgelser i lighed med CCSARP projektet er vigtige skridt på vejen til at udvikle og forfine de beskrivelsesapparater, som vi har til rådighed til at beskrive den faktiske sprogbrug, både hos indfødte sprogbrugere og hos sprogindlærere. Derudover har resultater af denne art et helt klart fremmedsprogspædagogisk sigte. I den kommunikative sprogundervisning sættes fokus på at udvikle sprogindlærerens evner til at klare sig i konkrete samtalesituationer på målsproget. Hovedparten af de funktionelle undervisningsmaterialer, som findes i dag, og som ofte bruges i den kommunikativt orienterede sprogundervisning, er primært udarbejdet på grundlag af lærebogs-forfatternes egne fornemmelser af, hvad der er gængs sprogbrug i bestemte samtalesituationer.

En undersøgelse fra Hawaii (Pearson 1985; Pearson 1986, 47-61), hvor sproget $i$ et undervisningsmateriale blev sammenlignet med eksempler på indsamlet sprogbrug, viste imidlertid, at der var forbavsende stor forskel på, hvad lærebogsforfatteren mente, var hensigtsmæssig sproglig adfærd i de pågældende situationer, og hvad der rent faktisk blev valgt af de folk, der blev spurgt. Flere nyere materialesamlinger (f.eks. Trosborg og McVeigh 1988) er derfor udarbejdet på grundlag af empiriske undersøgelser i lighed med CCSARP projektet.

\section{2. "Gatekeeper encounters"}

En amerikansk forsker, John Gumperz (1982), har arbejdet med at beskrive den interkulturelle kommunikation i de såkaldte "gatekeeper encounters" (GEs). GEs er samtalesituationer, hvor den ene af samtalepartnerne $\mathrm{i}$ kraft af sin faglige position har magt til at påvirke den andens liv i positiv eller negativ retning (har magten til at åbne og lukke "mulighedernes døre"). Der kan f.eks. være tale om samtaler med ens bank eller en sagsbehandler, jobsamtaler eller samtaler mellem lærer/elev eller ansat/chef.

I Gumperz' arbejde beskrives især de problemer, som kan opstå i samtaler mellem en sådan " $\varnothing v$ righedsperson" og en ikke-indfødt sprogbruger. De fleste sprogindlærere vil oftest ubevidst overføre deres sproglige normer fra modersmålet på målsproget. Der kan både være tale om helt konkrete sproglige udtryksmidler, i lighed med CCSARPs beskrivelse af sproghandlingsudtryk og om intonations- og betoningsforskelle. Der kan også være tale om forskelle i, hvordan man opbygger 
sin samtale (om de vigtigste sider af ens sagsfremstilling eller kvalifikationer skal nævnes først eller sidst; om man skal tage initiativet eller vente og besvare spørgsmål) eller i, hvad der forventes af en bestemt samtalesituation (f.eks. om man skal dokumentere sine færdigheder ved hjælp af anbefalinger; om man kan give udtryk for de problemer, man har haft; om man skal underbetone eller overdrive sine kvalifikationer, osv.).

Det er værd at bemærke, at personen i den magtfulde position i mange af de situationer, som Gumperz beskriver, på forhånd er positivt indstillet overfor den fremmedsprogede person. Det er derfor ekstra påfåldende, hvor nemt samtalen "kører skævt", fordi begge samtalepartnere ubevidst tolker den sproglige adfærd hos den anden på basis af sine egne (oftest også ubevidste!) sproglige normer. Ofte vil dette medføre så store misforståelser, at konflikt, frustration og en følelse af afmagt bliver et uundgåeligt resultat af dette kulturmøde. Negative stereotyper om den andens kultur forstærkes, og for den fremmedsprogede betyder det ofte en fastlåsning af situationen uden mulighed for forbedring af ens sociale vilkår. Gumperz foreslår, at beskrivelser af sådanne kultursammenstød og analyser af de ubevidste normer, der ligger bag den sproglige adfærd, kan bruges til at bevidstgøre "sagsbehandlere" i forskellige sammenhænge og dermed være medvirkende til at undgå, at situationer som de nævnte tilspidses og får uheldige konsekvenser for den fremmedsprogede "klient" (se Roberts, Davies og Jupp 1992 for en beskrivelse af arbejdet med studieprogrammer, der sigter mod en sådan "cross-cultural training").

\section{Indlæring af ordforråd}

Forskning vedrørende indlæring af ord er et af de områder indenfor FSP, som både grænser op til den traditionelle lingvistik (her især semantikken) og til den psykologiske forskning (indlæringsmodeller, modeller om kognitiv bearbejdning, teorier om korttids- og langtidshukommelsen, osv.).

Selvom mange af os oftest forbinder det at kunne et sprog med at kende og lære en masse fremmede ord, har systematisk undervisning i ordforråd overraskende nok været et af de områder, som i lange perioder har været forsømt indenfor sprogundervisningen. Interessen for at arbejde med ordforråd, både indenfor forskningen og indenfor under- 
visningen er dog stigende, hvilket udbuddet af nyere antologier med forslag til ordforrådsøvelser (se f.eks. Nation 1990; McCarthy 1990; og McCarthy og O’Dell, 1994) da også vidner om. Spørgsmålet om størrelsen af sprogindlæreres ordforråd og diskussion af metoder til at fremme elevers ordforståelse og til at styrke lagringen af ord $\mathbf{i}$ langtidshukommelsen er nogle af de fremherskende temaer i ordforrådsforskningen.

\subsection{Leksikalske gattestrategier}

I en af de største danske unders $\varnothing$ gelser af indlæring af ordforråd beskriver Kirsten Haastrup (Haastrup 1989, 20-35; Haastrup 1990, 120-133 og Haastrup, 1991), hvordan danske elever gætter ukendte ord på engelsk. Nøgleordene er her "inferencing” og "leksikalske gættestrategier", dvs. evnen til at kunne drage slutninger om ukendte ord i inputtet udfra forskellige videnskilder. Her er således ikke længere tale om at analysere og beskrive indlæreres sproglige produkt, men om at fors $\varnothing$ ge at beskrive de processer, som eleverne bruger til at nå frem til en forståelse af ordbetydninger. Som metode til at fange disse mentale processer anvendes to undersøgelsesmetoder, som supplerer hinanden:

I: Højttænkning: elevpar tænker højt om betydningen af ukendte ord i en tekst.

II: Retrospektion: interview med hver elev om deres gættestrategier umiddelbart efter højttænkningsøvelsen.

For at nå frem til en ordforståelse kan eleverne trække på en række forskellige videnskilder (se skema 3): 


\section{Skema 3: Hierarki over nøgler til ordforståelse}

\begin{tabular}{|ll|}
\hline $\begin{array}{l}\text { viden om verden } \\
\text { tekstmæssig sammenhæng } \\
\text { semantik }\end{array}$ & $\begin{array}{l}\text { TOPSTYRING } \\
\text { begrebsmæssig viden }\end{array}$ \\
ordsammenhæng (kollokation) & \\
syntaks & \\
ordklasse & \\
ordoprindelse & \\
leksis & \\
morfologi & sproglig viden \\
ortografi/fonologi & BUNDSTYRING \\
\hline
\end{tabular}

Som det fremgår af nedenstående eksempel fra højttænkningsøvelsen i skema 4, som er hentet fra Haastrup (1990, 127), kan eleverne vælge at fokusere på ordets sproglige form (bundstyring), eller de kan trække på en forståelse af konteksten og det emne/tema ordet forekommer i (topstyring).

Naturligvis vil valg af leksikalsk gættestrategi være afhængig af, hvilke nøgler til forståelsen det enkelte ord lægger op til. I eksemplet har ordet "insatiable" en sådan struktur (forstavelse-ordstamme-endelse), at det er oplagt her at bruge sproglige nøgler til forståelsen i samspil med andre, mere topstyrede strategier. De to elever nøjes f.eks. ikke med at fokusere på ordets form (= bundstyring), men forsøger, som vi har set, også at inddrage en forståelse af tekstsammenhængen ("han lyder som om han var ret fremadstræbende" = topstyring). Der er således tale om en samspilsforarbejdning med inddragelse af forskellige nøgler tll forståelse. 


\section{Skema 4: Eksempel fra en højttænkningsøvelse}

I forbindelse med nedenstående tekst er eleverne A og B konfronteret med ordet insatiable, der forekommer i følgende kontekst:"... a king called Chaka. He was a clever military leader with insatiable political ambitions. He won most of southeastern Africa...”. A og B's opgave er at gætte sig frem til betydningen af insatiable, og deres højttænkning er gengivet i protokolform:

A: able er noget med at være i stand til - insane - ins

$\mathrm{B}$ : jeg tror i hvert fald det er et positivt ord - eller noget med utroligt store

A: hvad betyder sati-

B: djævelsk - det er også en nægtelse - det er noget med $u$ - man kunne ikke dæmpe dem

A: hvorfor tror du det er en nægtelse

B: det plejer det at være - in- altså forstavelsen

A: (oversætter) han var en klog militærleder med ...

B: ubændige ubændige

A: han lyder som om han var ret fremadstræbende

A: in - sa - ti nå ja in er noget med

B: det er en nægtelse det er noget med $u$ - hvad er det for et godt ord hov forresten - sati- er noget med satisfy

A: ja det har jeg også tænkt på

Det interessante er, at der altså er tale om en såkaldt "samspilsforarbejdning" ("cross-talk model", Flores d'Arcais og Schreuder 1983, 143). Hermed menes, at eleverne ikke arbejder sig lineært igennem en forståelsesproces eller nøjes med én type strategi. Der er snarere tale om at:

1. Forarbejdning finder sted på mange niveauer samtidig.

2. Niveauerne kommunikerer direkte med hinanden.

3. Et eller flere niveauer kan springes helt over.

Ved at sammenholde data fra højttænkning og retrospektion med elevernes sproglige niveau (højt // lavt) kunne Haastrup (1990, 120-133) vise, at der er en klar sammenhæng mellem elevernes sproglige færdigheder og deres præference for bestemte typer af gættestrategier. Elever fra den laveste gruppe brugte flere bundstyrede strategier, hvorimod elever fra den højeste gruppe anvendte langt flere af de topstyrede strategier og var klart bedre til at bruge samspilsforarbejdning. 
Rent pædagogisk peger Haastrups undersøgelse på behovet for at bevidstgøre sprogindlærere om forskellige leksikalske gættestrategier og om fordelene ved at anvende en kombination af strategityper. Disse resultater sætter således fokus på arbejdet med at styrke elevernes sproglige viden og bevidsthed. Det er imidlertid vigtigt at understrege, at der ikke blot er tale om bevidsthed om sprogsystemet, i dette tilfælde ordforrådet, men snarere er tale om at styrke og udvikle elevernes procesviden. Ved at give eleverne et redskab til selv at arbejde med ordforståelse, f.eks. i forbindelse med læseprocessen, udvikles deres evne til selvindlæring; en evne, der rækker langt ud over klasseværelsets rammer. Som parallel hertil kan nævnes den pædagogiske opmærksomhed, der har været omkring arbejdet med at lære elever at bruge de produktive kommunikationsstrategier (f.eks. at kunne omkrive eller forklare et ord i tilfælde af en manglende glose, se Færch og Kasper 1983; Albrechtsen 1989, 36-47).

\subsection{Lagring af ord $i$ langtidshukommelsen}

Som nævnt fokuseres der i arbejdet med elevernes leksikalske gættestrategier på arten af de mentale processer, som kan aktiveres, når sprogindlæreren støder på en ukendt glose i inputtet. At kunne forstå (=afkode) et ords betydning er imidlertid kun den allerførste fase i selve indlæringsprocessen. Vi kender alle problemet med, at de nye ord, vi stifter bekendtskab med, ofte glemmes hurtigt igen. Et andet centralt spørgsmål indenfor ordforrådsindlæringen er derfor, om der findes kognitive faktorer, der fremmer lagringen af nylærte ord i langtidshukommelsen.

I den kognitive debat (Craik og Lockhart 1972, 67-84; Jacoby, Craik og Begg 1979, 585-600; Beheydt 1985, 1-18) er en af de hovedteser, som fremhæves, at ord, som dybdebearbejdes af indlæreren, også har større chance for at blive husket.

En af metoderne til at dybdebearbejde en bestemt glose kunne netop være arbejde med at anvende leksikalske gættestrategier i stedet for straks at slå ordet op i en gloseliste. Andre metoder, som nævnes, er $\emptyset$ velser, der kræver, at eleven anvender ordet $i$ en anden sammenhæn eller sproglig form, end den oprindeligt forekom $\mathrm{i}$ i inputtet. Kommunikative aktiviteter, hvor kendskab og brug af ordet er centralt for løsningen af en bestemt opgave, kunne f.eks. også sikre en sådan dybdebear- 
bejdning og dermed bedre lagring af glosen i langtidshukommelsen. Man kunne også nævne øvelser med antonymer, synonymer, overbegreber og ordfamilier (semantiske felter), hvor der arbejdes med en forståelse af ordets semantiske relation til andre gloser indenfor ordforrådet.

Det ville føre for vidt i denne sammenhæng at gå nærmere ind på disse teorier om indlæring gennem dybdebearbejdning eller at diskutere andre kognitive faktorer, som muligvis kan fremme og styrke indlæringen af ordforråd. Det er desværre heller ikke muligt, at give flere konkrete eksempler på de mange forskellige praktiske undervisningsmetoder, som er blevet foreslået til at støtte sprogindlærerens ordforrådstilegnelse (se igen f.eks. McCarthy 1990 eller McCarthy og O'Dell, 1994). Det er imidlertid vigtigt at påpege, at mange af de nye forslag til undervisningsmetoder, i lighed med nogle af de nævnte indenfor ordforrådsindlæringen, både inspireres af og finder deres teoretiske fundament i en mere almen viden om kognitive processer og indlæringsfaktorer.

\section{Den skriftlige dimension}

Den kommunikative fremmedsprogsundervisning, hvor nogle af de centrale nøgleord er "kommunikation", "formålsbestemt sprogbrug" og "kreative, elevcentrerede øvelser", har i høj grad sat fokus på sprogindlærerens mundtlige udtryksfærdighed. I de senere år er der også blevet større opmærksomhed omkring den skriftlige dimension, både i sprogundervisningen og i den fremmedsprogspædagogiske forskning. Den klassiske oversættelses- $\varnothing$ velse, som tidligere ofte var en af de mest fremherskende arbejdsformer til opøvning af sproglig præcision og til udvikling af elevernes mere generelle skriftlige kompetence, afløses nu ofte af andre genrer, herunder friere og mere kreative opgavetyper. Nøgleordene i den pædagogiske praksis er i dag "narrative og argumentative tekstgenrer", "fri skriftlig fremstilling", "procesorienteret skrivning" og "skriveværksteder".

Af pladsmæssige grunde vil det kun være muligt i denne sammenhæng kort at berøre to aspekter indenfor arbejdet med den skriftlige dimension: 1) et internordisk projekt, som gennem analyser af elevtekster forsøger at nå frem til en nærmere bestemmelse af tekstkvalitet og 2 ) et konkret forslag til arbejde med skriveprocessen i sprogundervisningen. 


\subsection{Nordskriv projektet}

Nordskriv projektet (Albrechtsen, Evensen, Lindeberg og Linnarud 1990, 79-91) er som nævnt et internordisk projekt, hvor 4 forskere fra henholdsvis Danmark, Norge, Sverige og Finland i samarbejde har forsøgt at belyse spørgsmålet om tekstkvalitet.

Hovedformålet med deres arbejde har været at beskrive den mere globale tekstopbygning (kohæsion og kohærens), dvs. at finde frem til en række analysemål, der kan anvendes til mere præcist at bestemme, hvad der adskiller tekster af forskellige kvalitet (bedømt udfra lærervurderinger) og fra forskellige uddannelsesniveauer.

I analyserne blev 4 sproglige områder, som anses for at skabe sammenhæng (kohæsion og kohærens) i tekster berørt:

1. Forbindere, dvs. brug af konjunktioner og sætningsadverbialer.

2. Pronominal og leksikalsk reference, dvs. sammenkæding af teksten vha. pronominer og brug af ordgentagelser/tematisk ordsammenhæng (f.eks. telefon - ringe - optaget - snakke).

3. Funktionelle roller, dvs. de enkelte sætningers funktion i tekstopbygningen (f.eks. tese/udbygning/kommentar/eksemplificering/ modargument/ kontrast, osv.).

4. Sekvenser af verbalformer, dvs. den normale fordeling af verbalformer i bestemte genrer (f.eks. narrative tekster=datid; argumentative tekster=nutid; instruktioner=imperativer).

Mht. spørgsmålet om forbindere viste analyserne, at man bør skelne mellem de konjunktioner og adverbialer, som mere lokalt kæder nærtstående sætninger sammen og de konjunktioner og adverbialer, som mere globalt skaber sammenhæng over længere sekvenser i teksten, f.eks. mellem den enkelte sætning og hele tekstsammenhænge. Det var især elevernes brug af de globale forbindere, der kunne diskriminere mellem den "gode" og den "dårlige" tekst.

Mht. analysen af pronominal og leksikalsk reference viste det sig, at de dårlige tekster havde mange små, korte kæder af reference. Dette viser, at mange forskellige emner blev introduceret, men at det samme emne ikke blev uddybet eller bearbejdet i dybden.

Denne mangel på opfølgning af samme emne(r) i de dårlige tekster, kom også frem i analysen af de funktionelle roller. Her viste det sig, at 
de gode tekster havde lange sekvenser af forskellige funktionelle roller, hvorimod de mindre vellykkede tekster var opbygget med ringe variation i valg af funktionelle roller og med en struktur, der primært bestod af korte sekvenser af disse tekstfunktioner.

Analysen af sekvenser af verbalformer viste også en forskel mellem teksterne. I de dårligere tekster var der langt flere "umotiverede" skift i verbalformer, hvorimod de gode tekster indeholdt langt flere "motiverede" skift, dvs. skift i verbalformer, der understregede bevidste brud i tekstens globale struktur/fokus (f.eks. et narrativt indskud i en argumentation; et flashback; osv).

Ser man mere sammenhængende på resultaterne fra de forskellige analysemål i forhold til de to tekstgrupper, viste analyserne, at den gode tekst var karakteriseret af: inddragelse af færre emner, mere dybdebearbejning af det samme emne, større variation i strukturopbygningen og en bedre beherskelse af de globale forbindere.

Mere overordnet viste resultaterne fra de forskellige analyser klart, at de mål som mere globalt beskriver en teksts opbygning i langt højere grad kan bruges til at diskriminere mellem tekster af forskellig kvalitet end mere lokale analysemål. Derudover er det dog vigtigt at inddrage forskellige analysemål, dvs. at se på en kombination af de forskellige elementer, der kæder en tekst sammen, for at nå frem til en forståelse af samspillet mellem lokal og global kohærens.

Disse resultater peger på, at det er af afgørende betydning at se på den mere overordnede struktur i en tekst og at forsøge at belyse, hvilke tilgange eleven har anvendt i forbindelse med opbygningen af sin tekst.

Analysen af de gode tekster viste klart, at eleverne her havde holdt sig til en uddybning af enkelte af de emner, som det kunne være relevant at berøre, og som evt. skitseagtigt blev nævnt i tekstens indledende afsnit. De dårligere tekster var derimod karakteriserede ved at ophobe og nævne emner/problemstillinger, som aldrig eller kun sporadisk blev berørt i teksten.

Resultaterne synes også at vise, at eleverne har en forskellig tilgang til deres skriveproces. Den mindre vellykkede tekst er et resultat af en mere associerende og ophobende tilgang til emnet, hvor eleven fra det ene emne til det andet associerer sig videre gennem stoffet. Den gode tekst er derimod et resultat af en mere analytisk tilgang til emnet, hvor teksten bygges op mere hierarkisk, således at de enkelte afsnit får en 
klar funktion i forhold til hinanden og i forhold til en bearbejdning af emnet(erne). Den mere analytiske tilgang til stoffet giver langt mere mulighed for at skriveprocessen, f.eks. i forbindelse med udarbejdelse af mere argumentative teksttyper, ikke blot bliver en gengivelse af allerede tilegnet viden ("knowledge-telling"), men også bliver en bearbejdnings-og-forståelsesproces for den skrivende ("knowledge-transforming"). Herved bliver skrivearbejdet ikke blot vigtigt som et rapporterings-og meddelelsesmiddel, men som et redskab til at erhverve ny erkendelse og viden.

\subsection{Processkrivning og skriveværksteder}

I de seneste år har traditioner og erfaringer fra bla. de amerikanske universiteter, hvor de studerende indføres systematisk i skriveteknikker, været en inspirationskilde i forbindelse med indførelse af en ny skrivepædagogik ved en række danske undervisningsinstitutioner.

Netop nøglebegreber som skriveværksteder, processkrivning, elev-feedback, narrative og argumentative tekster vidner om en ny pædagogisk praksis, hvor skriveprocessen faseopdeles, og hvor eleverne arbejder med en række forskellige tekstgenrer.

Christian Kock og Birthe Tandrup beskriver i deres bog "Kreativ Skrivning" (Kock og Tandrup 1989) grundprincipperne i denne nye tilgang til skrivearbejdet. Arbejdet deles op i 3 forskellige faser: forberedelse, formulering og forbedring.

Denne opdeling er velkendt, men der er tale om en klar fokusering på den indledende fase $\mathrm{i}$ arbejdsprocessen, hvor den skrivende, enten alene eller i samarbejde med andre, samler og ordner sin viden om emnet, eventuelt i form af "brainstorming"- $\varnothing$ velser. Efter denne forberedelsesfase, hvor den indsamlede viden ordnes og bearbejdes, skrives et første udkast ("first draft"). Der lægges derefter vægt på, at rettefasen, bliver så konstruktiv som mulig, så den skrivende får retningslinier, enten af læreren eller sine kammerater, som kan bruges ved den nye gennemarbejdning af teksten.

Der er en række vigtige principper, som fremhæves i den procesorienterede skriveundervisning: 
1. At der arbejdes med én fase ad gangen.

2. At den skrivende kan gå frem og tilbage mellem faserne i arbejdsprocessen.

3. At den skrivende kan gå frem og tilbage i teksten.

Disse principper baseres på en forståelse af, at skriveprocessen ikke er en uafbrudt, lineær proces, hvor den skrivende sætter pen til papir og ikke standser, før det endelige produkt er færdigt. Det at skrive skal snarere ses som en dynamisk, cyklisk proces, hvor denne vekselvirkning mellem indhentning af viden, bearbejdning, formulering, erhvervelse af ny viden, rettelse, osv. er en forudsætning for et godt arbejdsresultat.

Viden om tekstkvalitet $i$ lighed med de resultater, som er beskrevet ovenfor i forbindelse med gennemgangen af Nordskriv projektet, er et vigtigt redskab i den procesorienterede skriveundervisning. Indsigt $\mathrm{i}$ hvilke faktorer, der kendetegner den gode teksttype, som f.eks. spørgsmålet om sekvenser af funktionelle roller, typen af leksikalsk reference eller sekvenser af verbalformer, er nødvendigt for, at eleverne og lærerne kan arbejde systematisk med at diagnosticere og rette mangler i teksten i rettefasen. Forskningsresultaterne sætter også fokus på nødvendigheden af at arbejde med den globale tekststruktur. Faseopdelingen af arbejdet kan være med til at at udvikle elevernes evne til at arbejde på en ny måde med stoffet, der bygger på en mere analytisk ("knowledge-transforming") tilgang snarere end den mere associerende eller ophobende stil ("knowledge-telling").

\section{Pædagogisk udviklingsarbejde}

Afslutningsvis vil jeg gerne præsentere et eksempel på et pædagogisk udviklingsarbejde, som jeg selv har gennemført i samarbejde med en erfaren engelsklærer (se Henriksen 1988, 171-193; Henriksen 1989, 166-182 og Henriksen 1990). Formålet med dette fors $ø g$ var at afprøve, om det var muligt at inddrage forskellige kommunikative opgavetyper og arbejde med det pragmatiske aspekt (se punkt 3 ovenfor om den tværsproglige pragmatik) $i$ en mere traditionel undervisningssammenhæng som det danske gymnasiesystem.

I gymnasiets engelskundervisning lægges der traditionelt stor vægt på at oparbejde en høj grad af sproglig præcision hos eleverne. Dette betyder at arbejde med grammatik og med de skriftlige opgaver indgår 
som en fast bestandel af undervisningen. Derudover er den sproglige indlæring tæt forankret i tekstlæsningen, dvs. arbejdet med at læse og fortolke (fortrinsvis) litterære tektster.

Jeg fandt, at det var overordentligt vigtigt for projektets eventuelle gennemslagskraft, at forsøge at finde måder at indpasse de nyere fremmedsprogspædagogiske teorier om sprogbrug og om elev-centrerede, kreative arbejdsformer i denne undervisningstradition, istedet for at forsøge at skitsere nogle tilgange, som eventuelt ville skabe problemer for lærer og elever i forhold til de eksisterende fagbekendtgørelser og eksamensforordninger.

Forsøget strakte sig over 1 skoleår, hvor jeg som medplanlægger og observatør fulgte undervisningen i en 1.g. nysproglig. I løbet af året arbejdede eleverne med en lang række forskellige kommunikative arbejdsformer, som læreren og jeg i samarbejde havde forsøgt at tilpasse til det daglige tekstarbejde. Derudover blev eleverne undervist helt eksplicit i forskellige sprogbrugsfænomener (sproghandlinger, høflighedsstrategier og samtaleregulerende udtryk (de såkaldte gambits, se Albrechtsen 1989, 36-47 for en kort oversigt. Se også bilag 1)).

Over halvdelen af timerne blev optaget på lydbånd, hvilket gav mig muligheden for at analysere det sprog, som blev produceret, både i den lærerstyrede undervisning og i de små elevgrupper. Eleverne udfyldte også en række små skriftlige mini-rollespil (DCTs i lighed med CCSARP) ved forsøgets begyndelse og afslutning. Derudover blev alle eleverne interviewet i et spørgeskema og optaget på lydbånd til den mundtlige årsprøve ved skoleårets afslutning.

Som nævnt var forsøget inspireret af to forskellige forskningsområder indenfor FSP:

1. Teorierne om den kommunikative fremmedsprogsundervisning (KFU).

2. Den nyere pragmatiske forskning.

I den KFU arbejdes der meget med at bryde den traditionelle, lærerstyrede undervisningsform ved at lade eleverne arbejde alene, i par eller $\mathrm{i}$ elevgrupper med en række forskellige arbejdsformer. Dette kan være arbejde med forskellige former for opgaveløsning, rollespil, eller med f.eks. projektarbejde. 
Formålet med denne ændring af arbejdsmønstret er dels at give eleverne langt mere taletid på målsproget. Derudover skulle den elevcentrede arbejdsform lægge mere af det sproglige initiativ over på eleverne og give dem mulighed for at bruge sproget i en række situationer, som ligner de kommunikationssituationer, som eleverne vil møde i det virkelige liv udenfor klasseværelset. Eleverne skulle herigennem få lejlighed til (f.eks. gennem en række rollespil) at træne brugen af forskellige høflighedsudtryk.

Analyserne af det indsamlede klasseværelsesmateriale (se Henriksen 1989, 166-182 og Henriksen 1990) viste klart, at ændringen i arbejdsformerne gav eleverne mulighed for at bruge målsproget langt mere aktivt og på en kvalitativt anderledes måde end i de lærerstyrede timer. I de elevcentrede opgavetyper brugte eleverne, som ventet, langt flere forskellige sproghandlingstyper og samtaleregulerende mekanismer ("gambitter"). Derudover blev eleverne, i kraft af opgaveløsningskravet i mange af opgaverne, tvunget til at strække deres sproglige ressourcer og anvende en række kommunikationsstrategier istedet for at opgive eller spille initiativet tilbage til læreren.

Ser man på arbejdet med at bevidstgøre eleverne om forskellige sprogbrugsfænomener viste det sig, at det var forholdsvis nemt at arbejde med disse aspekter i undervisningen. Pga. det store antal potentielle sproghandlingstyper og sprogbrugssituationer med varierende krav til f.eks. høflighedsmarkeringer, der findes i den naturlige kommunikation, var det imidlertid kun muligt i løbet af forsøgsperioden at nå at arbejde eksemplarisk med en enkelt sproghandlingstype (anmodninger) og med de samtaleregulerende gambitter.

Analyserne af de indsamlede DCTs viste, at der kunne spores en svag udvikling i elevernes beherskelse af disse sproglige træk. Optagelserne fra årsprøverne viste mere tydeligt, at eleverne var i stand til at tage en lang række initiativer i samtalen; at de beherskede de sproglige mekanismer til at tage og fastholde ordet, og at de langt hen ad vejen var i stand til at strække deres sproglige ressourcer udover, hvad der var forventeligt på dette sproglige niveau.

Som nævnt ovenfor var det vigtigt at forsøge at indpasse projektet $\mathrm{i}$ den normale undervisningspraksis i gymnasiet. Eleverne blev derfor også undervist i grammatik og den lærerstyrede klasseundervisning blev ikke afskaffet, men indgik på linie med de mere elevcentrerede arbejdsformer i det daglige arbejde. 
Fokuseringen på de forskellige sprogbrugsfænomener viste sig overraskende at have en positiv, afsmittende effekt på elevernes grammatiske forståelse. Eleverne var langt villigere til at arbejde med mere traditionelle grammatiske problemstillinger og var langt mere åbne overfor at diskutere grammatiske grænsetilfælde og variation i grammatisk brug, end læreren nogensinde tidligere havde oplevet på dette klassetrin.

Det eneste sted, hvor forsøget havde en mere negativ effekt, var i relation til elevernes ordforrådsindlæring. Arbejdet med de nye sider af faget betød, at klassen ikke fik læst nær så mange tekster, som elever normalt gennemarbejder på et skoleår. Dette kunne forklare, at elevernes ordforråd ikke var så varieret som man kunne have forventet i forhold til deres generelle kommunikationsfærdighed. Dette resultat betyder, at behovet for at finde kommunikative arbejdsformer, der direkte relaterer sig til den litterære tekstlæsning bliver endnu mere presserende, hvis eleverne også skal udvikle deres sprogfærdighed på det leksikalske område (se bilag 2 for en oversigt over forslag til en lang række forskellige kommunikative opgavetyper i forbindelse med læsning af tekster).

En af hoveddiskussionspunkterne indenfor den sprogpsykologiske forskning vedrører spørgsmålet om betydningen af at udvikle elevernes sproglige viden og bevidsthed. Vælger vi at bruge kostbar undervisningstid på det metakommunikative arbejde, i lighed med arbejdet med sproghandlingsaspektet, som jeg netop har skitseret, må vi som undervisere imidlertid nok revurdere vores forventninger vedrørende det umiddelbart målelige udbytte af en sådan undervisning. Effekten af dette arbejde vil måske ikke slå så hurtigt igennem i elevernes sproglige produktion. Udbyttet vil snarere være mere langsigtet $\mathrm{i}$ forhold til elevernes sproglige opmærksomhed overfor det input, de støder på, f.eks. udenfor undervisningen. Eller sagt på en anden måde: eleverne vil få et redskab, der gør dem i stand til at tolke og systematisere den mængde af ustruktureret input, som de ofte bombarderes med udenfor klasseværelsets rammer. Herved bliver de i stand til at arbejde videre med deres egen indlæringsproces. I den mere begrænsede undervisningstid vil eleverne derimod kun få mulighed for at træne deres kommunikationsfærdighed indenfor en række eksemplariske områder. 


\section{7. $\quad$ FSP og grønlandskfaget på GU}

Når man vil diskutere den umiddelbare overførselsværdi af resultater og erfaringer fra den fremmedsprogspædagogiske forskning til en konkret undervisningssammenhæng, som f.eks. den grønlandske, er det nødvendigt at vurdere både de sprogpolitiske forhold og undervisningstraditionen på det pågældende sted.

For grønlandskfagets vedkommende gælder dette måske i endnu højere grad end så mange andre steder, da der af historiske grunde er en række sprogpolitiske forhold, der hele tiden medtænkes i beslutningsprocesserne på alle niveauer. Derudover gælder det, at mange elementer i den fungerende undervisningstradition er "lånt" fra en anden undervisningssammenhæng, nemlig den danske, og derfor indeholder undervisningen komponenter (både indholdsmæssige og undervisningsstrategiske), som er udsprunget af en helt anden undervisningssituation end den, den grønlandske gymnasievirkelighed befinder sig i i dag.

Det er mit indtryk, at grønlandskfaget i disse år er inde i en rivende udviklingsproces, hvor fagets indholdsmæssige og didaktiske identitet ændres radikalt, bla. i takt med en stigende fokusering på fagets centrale position som modersmålsfag i gymnasiet. Lærerne er de personer, som kender fagets potentialer og problemer indefra, og som dermed er bedst egnede, som fagfolk, til at være med til at præge udviklingen $i$ årene fremover. En så central rolle stiller krav om en stærk faglig identitet hos fagets undervisere.

Det er i lyset af en sådan faglig udviklingsproces, at jeg føler, at den fremmedsprogspædagogiske forskning, kan give nogle redskaber til at diagnosticere den pædagogiske situation og til at vælge de mest hensigtsmæssige strategier til at løse den pædagogiske opgave, som den konkrete undervisning stiller.

For grønlandskfagets vedkommende kompliceres forholdene også af, at der er tale om to dele af faget (niveau a:modersmålsfaget og niveau b:grønlandsk som andetsprog/begyndersprog) med forskellige formål og indholdskrav. At FSP har noget at byde på er helt oplagt i forhold til undervisning på niveau $\mathrm{b}$, hvor arbejdet med elevernes sproglige kompetence på grønlandsk står i centrum. Da sproget som meddelelsesmiddel og som bærer af den kulturelle arv, også står i centrum i undervisningen på niveau a, mener jeg imidlertid også at en række af de 
problemstillinger, som behandles indenfor den sprogpædagogiske forskning kan være en inpirationsfaktor i den faglige debat om udformningen og udviklingen af grønlandsk som modersmålsfag.

Når jeg taler om betydningen af den sprogpædagogiske forskning tænker jeg ikke blot på helt konkrete sprog- eller litteraturpædagogiske løsningsforslag, som vedrører den daglige pædagogiske praksis, f.eks. med ideer til opgavetyper, analyser af klasseværelsesaktiviteter, konkrete ideer til en ny skrivepædagogik, lærebogsudvikling, osv.

En meget stor del af den nyere sprogpædagogiske forskning kan i dag karakteriseres som sprogpædagogisk grundforskning, hvor der arbejdes med at udvikle og afprøve en række mere sprogindlæringsteoriske og sprogbeskrivelsesmæssige modeller.

Den sprogpædagogiske forskning har f.eks. haft stor betydning for udviklingen af et mere komplekst og nuanceret sprogsyn. Ved f.eks. at inddrage de pragmatiske og diskursmæssige komponenter i sprogfærdighedsbeskrivelsen, har FSP været med til at udvikle vores generelle forståelse af sproget som system og som kommunikationsmiddel. Arbejde med analyser af tekstkvalitet, i lighed med Nordskriv projektet, biddrager også til en større forståelse af en række centrale sproglige mekanismer.

Indsigt af denne art er naturligvis vigtigt i et sprogindlæringsfag, men kan også være et vigtigt redskab i enhver faglig sammenhæng, hvor der arbejdes med at udvikle elevers evne til at udtrykke sig gennem sproget og til at arbejde analystisk. Her tænker jeg bla. på litteraturundervisningen, hvor der arbejdes med fortolkninger baseret på en nærlæsning af tekstens ordvalg og struktur, og hvor der arbejdes med forskellige tekstgenrer og sproglige udtryksmidler.

Som jeg har været inde på tidligere kan forskning indenfor pragmatikken (f.eks. CCSARP projektet) og den interkulturelle kommunikation (f.eks. Gumperz' arbejde) sætte fokus på forskelle og ligheder mellem sprog, som vi som sprogbrugere ikke nødvendigvis er bevidste om, men som har stor betydning, når vi ser på sproget som et praktisk kommunikationsmiddel. Indsigt af denne art er ikke blot et vigtigt redskab for sprogindlæreren, men kan i høj grad også være et centralt tekstanalytisk redskab til f.eks. at afdække de interpersonelle relationer mellem personerne i de litterære tekster og til at forklare konflikter, som beskrives og behandles i de læste tekster. 
Viden om sprogkulturelle forskelle kan være med til at mindske konsekvenserne af potentielle kultursammenstød og kan give os nogle konkrete løsningsforslag på, hvordan kommunikationssammenbrud undgås i en multi-etnisk sammenhæng (se især Roberts et. al. 1992). Viden om disse forhold er derfor vigtige i en mere overordnet, samfundspolitisk sammenhæng, der rækker langt udover klasseværelsets rammer. Det er vigtigt at slå fast, at Gumperz i sit arbejde betoner betydningen af at bevidstgøre de personer, som sidder i magtpositionen (f.eks. læreren) snarere end sprogindlæreren selv.

Afslutningsvis vil jeg gerne pointere, at der i hovedparten af de forskningsprojekter, som jeg har beskrevet, arbejdes med sprog, som rent sprogopbygningsmæssigt adskiller sig fra grønlandsk. Dette kan givetvis have betydning $\mathrm{i}$ forhold til den umiddelbare tolkning og overførselsesværdi af forskningsresultaterne. Her tænker jeg mere konkret på f.eks. Haastrups undersøgelse af sprogindlæreres gættestrategier eller på Nordskriv projektets analyser af de sproglige mekanismer, som skaber tekstsammenhæng.

Derudover er det vigtigt at understrege, at flere af de nævnte projekter indgår i en indlæringssammenhæng, hvor målsproget indlæres som fremmedsprog og ikke som andetsprog. For grønlandsk b er der jo netop tale om en andetsprogssammenhæng, hvor målsproget (grønlandsk) anvendes udenfor klasseværelsets rammer i det omliggende samfund. Endvidere kompliceres billedet af, at elevernes udgangssprog i de fleste tilfælde er dansk, og at dette sprog igen har(havde) nogle bestemte funktioner i den grønlandske sammenhæng. Disse forskelle i sprogsituationen må naturligvis også medtænkes i vurderingen af de konkrete forskningsresulter.

\section{Bibliografi}

\section{Oversigtsværker}

Kasper, G./Wagner,J. (1989): Grundbog i Fremmedsprogspadagogik. København:Gyldendal. (i bibliografien:GIF,1989)

Phillipson, R../Kellerman,.E../Selinker, L. ./Sharwood Smith, M. ./ Swain, M. (1990): Foreign/Second Language Pedagogy. A Commemorative Volume for Claus Farch. Clevedon:Multilingual Matters. (i bibliografien:F/SLPR, 1990) 


\section{2. Øvrige referencer}

Albrechtsen, D (1989): Fremmedsproglig Produktion - at tale.I:GIF,1989, 36-47.

Albrechtsen, D./Evensen,L.S./Lindeberg,A.C./Linnarud,M. (1990): Analysing Developing Discourse Structure: The NORDWRITE Project. In: F/SLPR,1990, 79-91.

Beheydt, L. (1985): The Semantisation of Vocabulary in Foreign Language Learning. Unpublished paper fra kongres, Barcelona, 1985, 1-18.

Blum-Kulka, S. (1990): Interlanguage Pragmatics: The Case of Requests. In: F/SLPR, 1990, 255-271.

Blum-Kulka, S./House,J./Kasper,G. (1989): Cross-Cultural Pragmatics:Requests and Apologies. Advances in Discourse Processes. Vol. 31. Norwood, NJ:Ablex.

Craik, F.J.M./Lockhart, R.S. (1972): Levels of Processing: A Framework for Memory Research. In: Journal of Verbal Learning and Verbal Behaviour, 11, 671-84.

Edmondson, W./House,J. (1990): Do Learners Talk Too Much? The Waffle Phenomenon in Interlanguage Pragmatics. In: F/SLPR, 1990, 273-287.

Flores d'Arcais, G.B./Schreuder,R. (1983): The Process of Language Understanding: A Few Issues in Contemporary Psycholinguistics. I:Flores d'Arcais, G.B./Jarvella,R.J. (red.): The Process of Language Understanding, John Wiley \& Sons, 1-41.

Færch, C./Kasper, G. (1983)(red.): Strategies in Interlanguage Communication. Harlow: Longman

Gumperz, J. (1982)(red.): Language and Social Identity. Cambridge: Cambridge University Press.

Henriksen, B. (1988): Udvikling af sprogelevers pragmatiske bevidsthed - et pædagogisk fors $\varnothing$ g i gymnasiets engelskundervisning. In: Hansen, E. (red.): Sproglig Bevidsthed. København: Danmarks Lærerhøjskole, 171-193.

Henriksen, B. (1989): Elevcentrerede arbejdsformer i den kommunikative fremmedsprogsundervisning. In: GIF,1989, 166-182.

Henriksen, B. (1990):It's no Use without Use: Udvikling af fremmedsprogselevers pragmatiske kompetens - et dansk undervisningsprojekt. Licentiatafhandling, Københavns Universitet.

Haastrup, K. (1989): Fremmedsproglig reception:Lytte-og Læseforståelse. In: GIF, 1989, 20-35.

Haastrup, K. (1990): Developing Learners' Procedural Knowledge in Comprehension. In: $F / S L P R, 1990,120-133$.

Haastrup, K. (1991): Lexical Inferencing Procedures or Talking about words. Tübingen:Gunter Narr.

Jacoby, L.L./Craik,F.J.M./Begg,J.: Effects of Decision Difficulty on Recognition and Recall. In: Journal of Verbal Learning and Verbal Behaviour, 18, 585-600.

Kasper, G./Trosborg,A. (1989): Pragmatik. In: GIF,1989, 120-134.

Kock, C./Tandrup,B. (1989): Skriv Kreativt. Skriftlig Fremstilling:sagprosalfiktion. København: Gyldendal.

McCarthy, M. (1990): Vocabulary. Oxford: Oxford University Press. 


\section{4}

McCarthy, M../O’Dell, F. (1994): English Vocabulary in Use. Cambridge: Cambridge University Press.

Nation, I.S.P. (1990): Teaching \& Learning Vocabulary. Boston, Mass: Heinle \& Heinle.

Pearson, E. (1985): Aggreement and Disagreement: A Study of Speech Acts in Discourse and ESL/EFL materials. I:Occasional Paper Series. Department of English as a Second language:University of Hawaii at Manoa.

Pearson, E. (1986): Agreement/disagreement - an example of results of discourse analysis applied to the oral English classroom. In: I.T.L Review of Applied Linguistics 1986, 74, 47-61.

Roberts, C./Davies,E./Jupp,T. (1992): Language and Discrimination.A Study of Communication in Multiethnic Workplaces. London: Longman.

Trosborg, A. /McVeigh, J. (1988): Rules and Roles. Systime. 


\section{BILAG 1: GAMBITTER}

GAMBITTER: Oprindeligt udtryk for begyndelsestræk i skak. Ordet stammer fra det italienske "GAMBETTO" = at spænde ben (gamba = leg).

Gambitter er blevet defineret som "sproglige elementer, hvis primære funktion er at opretholde og regulere samtaler"

(Fra Færch,C./Kasper,G.: "Ja und? og Hva så? - a contrastive discourse analysis of gambits in German and Danish". I Fisiak,J.(1983) (red.) Contrastive Linguistics, The Hague:Mouton.)

Gambitter kan også beskrives som "samtalens olie", idet de ikke bidrager til samtalen rent indholdsmæssigt, men sikrer, at den holdes igang og glider. Gambitter styrer altså diskursfunktionerne i en samtale, dvs. de gør det muligt for den talende at:

1. at få ordet (TURNTAKING)

2. at holde ordet (TURNKEEPING)

3. at give ordet fra sig (TURNGIVING)

4. at lytte opmærksomt og signalere dette til samtalepartneren (UPTAKING)

5. at markere overgange i ens talestrøm (MARKING)

Eksempler på danske gambitter:

1. TURNTAKING ja, jo, jamen, altså, nå men, men, tjah, forresten, hør lige, stop lige, ved du hvad, hov, hvad var det jeg ville sige, nu vi taler om, helt ærligt, jeg synes

2. TURNKEEPING det jeg ville sige er...., (men) hvad skal jeg sige, for det først, altså, hvad er det nu det hedder, på den ene side, lad mig tænke mig om, mens jeg er ved det, lad mig lige se, det jeg mener er, faktisk (bemærk!:mange af disse gambitter er oftest ledsaget af fyldte pauser: er(m), mmh)

3. TURNGIVING ikke, vel, hva, okay, synes du ikke, synes du vel, ikke også, enig, er det rigtigt, hvad mener du, har jeg ret, mener du ikke

4. UPTAKING hm, mhm, ja, nå, nej, ok, ah, aha, nå for pokker, virkeligm er det rigtigt, det siger du ikke, enig, er det sandt, netop, akkurat, ja selvfølgelig, naturligvis, det passer 


\section{MARKING}

Derudover kan modtageren give "uptaking" vha. en lang række, emre følelsesladede kommentarer: F.eks.: hvor groft, guud nej, du milde, du godeste, hvor dårligt, åh nej da, jamen dog, aldrig, du store, den er feset ind, etc.

godt, fint, okay, forresten, forøvrigt, altså, det var det, nu til noget helt andet

Der findes en lang række gambitter udover de nævnte eksempler - listen giver kun et fingerpeg om nogle af de hyppige. Mange af de nævnte diskursfunktioner reguleres også vha. andre træk end gambitter, f.eks. ved $\varnothing$ jenkontakt, intonation, taletempo, og gentagelse af samtalepartnerens ytringer, men disse midler kombineres oftest med gambitter. Mange af de nævnte gambitter kan godt bruges til flere af de 5 diskursfunktioner (f.eks. kan 'godt' både bruges til UPTAKING og MARKING).

Ved at holde talestrømmen jævnt flydende, giver gambitten den talende tid til at tænke sig om, mens hun leder efter ordene og planlægger sine ytringer. Gambitterne fungerer således som en slags "sproglige heller" i produktionsprocessen. Sprogeleven kan ved at lære at bruge målsprogets gambitter:

1. vinde kostbar tid og øge sin fluency

2. få større ressourcer til at deltage $\mathrm{i}$ opbygningen af samtalen og dermed få en mere udfarende rolle i samtalen

3. give sit sprog et mere ægte talesprogspræg

Det er vigtigt at påpege, at valget af gambitter - i lighed med andre sproglige træk - naturligvis vil være afhængig af en lang række faktorer i samtalesituationen, f.eks. den talendes alder, sociale og geografiske tilhørsforhold, hvem der tales med, osv. Dette betyder, at der vil være nogle gambitter, som sprogeleven skal lære at beherske produktivt, hvorimod andre gambitter vil være så situationelt markerede, at sprogeleven bør være varsom med at anvende dem selv. Et bredt receptivt kendskab til en lang forskellige gambitter vil imidlertid være med til at øge sprogelevens receptive færdigheder, idet en sikker afkodning af gambitterne vil give sprogindlæreren et langt større overskud til at takle det egentlige sproglige budskab. 
BILAG 2: EKSEMPLER PÅ TEKSTRELATEREDE OPGAVEFORMER 
